\title{
Genotype Phenotype Correlation of FMF Cases in East Delta of Egypt: 2 Years of Follow-up \\ Mohamed Almalky', Rania Amir ${ }^{2}$, Eman Gamal Baz ${ }^{1}$
}

${ }^{1}$ PID Unit, Department of Pediatrics, Faculty of Medicine, Zagazig University, Egypt

${ }^{2}$ Microbiology and Immunology Department, Faculty of Medicine, Zagazig University, Egypt

*Corresponding author: Mohamed A Almalky, Mobile: (+20) 01144444929, E-Mail: drmohamedalmalkyped@yahoo.com

\begin{abstract}
Introduction: Familial Mediterranean fever (FMF, MIM\# 249100) is an autosomal genetic disease. FMF shows a marked ethnic distribution being most frequently observed in Turkish, Armenian, Jewish and Arabic communities. Since the cloning of the MEFV gene, about 280 mutations have been associated with FMF. M694V, V726A, E148Q, M694I, and M680I are the five most frequently encountered mutations.

Objective: The aim of this work was to correlate the clinical phenotypes of FMF patients to their gene mutation.

Patients and methods: The study was done on 55 patients with FMF who were diagnosed primarily clinically using Turkish pediatric criteria. Genetic identification of their gene mutation was performed and only patients with definite identified mutation in MEFV were included.

Results: Fever was the most prevalent manifestation in our patient as $96.3 \%$ of them experienced fever and the second most frequent symptom was abdominal pain $90.9 \%$ followed by chest pain $81.8 \%$. Family history was positive in $61.8 \%$. At diagnosis fifteen patients had amyloidosis at (27.3\%) while forty patients did not have elevated amyloid (72.7\%). Fifty one patient showed good response to colchicine $(92.7 \%)$ while only four did not show response $(7.3 \%)$. The severity of attacks were mild in 29 patients (52.7\%) and moderate in 6 patients (10.9\%) and severe in 20 patients (36.4\%). M694V was the most prevalent mutation followed by M694I, V726A, M680I, R761H and K695R respectively.

Conclusion: In Egypt no significant difference between homozygous and heterozygous FMF patients regarding their clinical presentations but type of mutation affects the severity of clinical presentation.
\end{abstract}

Keywords: East Delta of Egypt, Genotype Phenotype Correlation of FMF.

\section{INTRODUCTION}

Familial Mediterranean fever (FMF, MIM\# 249100) is an autosomal genetic disease that was described for the first time in $1945^{(1)}$. FMF shows a marked ethnic distribution being most frequently observed in Turkish, Armenian, Jewish and Arabic communities $^{(2)}$. Disease onset before 20 years of age in $90 \%$ of cases and, in $60 \%$ of cases, the age at onset is under 10 years. Nonetheless, the disease may develop after the first years of life ${ }^{(1)}$. Between recurrent and self-limited attacks of fever, severe abdominal, articular, and/or chest pain, patients with FMF are usually free of symptoms. Amyloidosis due to chronic inflammation leading to renal failure is the major complication of this disease ${ }^{(3)}$. Colchicine is an oral drug used for preventing or treating attacks. Daily intake of colchicine (1-2 mg) has been the recommended treatment for FMF since its introduction in $1972^{(\mathbf{1}, \mathbf{4})}$. Three sets of clinical diagnostic criteria have been identified: Tel Hashomer criteria ${ }^{(\mathbf{3})}$, Livneh criteria $^{(5)}$ and more recently Turkish pediatric criteria ${ }^{(6)}$. Different studies had been published to compare both sensitivity and specificity of those criteria and concluded that Turkish pediatric criteria is more sensitive and more specific than Tel Hashomer criteria although both had low specificity ${ }^{(7)}$. As in some cases, patients do not meet the clinical diagnosis criteria ${ }^{(5)}$, genetic diagnostic tests can be used to detect FMF gene mutations (MEFV mutations) that was identified in $1997^{(3,8)}$.

MEFV is located on chromosome $16 \mathrm{p} 13.3$ and formed of 10 exons, which encode a protein named pyrin which play role in the regulation of both inflammation and apoptosis ${ }^{(3)}$.

Since the cloning of the MEFV gene, about 280 mutations have been associated with $\mathrm{FMF}^{(8)}$. M694V, V726A, E148Q, M694I, and M680I are the five most frequently encountered mutations and account for $74 \%$ of FMF mutations in typical patients and the rest of the mutations are very rare in different populations $\mathbf{9}^{(\mathbf{9}, \mathbf{1 0})}$. Differences in clinical presentation of FMF among different ethnic groups have been studied $\left.{ }^{(\mathbf{1 1},} \mathbf{1 2}\right)$. However, phenotype-genotype correlations in FMF have not been decisively resolved ${ }^{(4)}$. The aim of this work is to correlate the clinical phenotypes of FMF patients to their gene mutation.

\section{PATIENTS AND METHODS}

The study was done on 55 patients with FMF who were diagnosed primarily clinically using Turkish pediatric criteria $^{(6)}$.

\section{Ethical approval:}

An approval of the study was obtained from Zagazig University Academic and Ethical Committee. Written informed consent was taken from parents for participation in the study after being 
informed about the aims and process of the study as well as applicable objectives.

\section{Inclusion criteria:}

- Age from 1- 16 years

- Both sexes

- Patients diagnosed primarily clinically using Turkish pediatric criteria.

- Patient with definite identified mutation in MEFV.

\section{Exclusion criteria:}

- Patients with autoinflammatory disorders not fulfilling criteria for FMF diagnosis

- Age more than 16 years or less than 1 year

- Patients with other comorbid disorders like Juvenile Idiopathic Arthritis (JIA).

\section{All patients had:}

- Full medical history including positive family history of FMF and medication history including colchicine.

- Thorough clinical examination.

- Laboratory tests including:

1. CBC, CRP, ESR, urine analysis.

2. Amyloid level in serum before and after treatment.

3. Abdominal ultrasound.

4. Genetic identification of their gene mutation was performed as published. Briefly, DNA was extracted from $100 \mu \mathrm{l}$ of blood with a commercial kit FMF StripAssay ( ${ }^{\circledR}$ kit Vienna Lab Diagnostics, Vienna, Austria. The procedure included three steps: (1) DNA isolation, (2) PCR amplification using biotinylated primers, (3) hybridization of amplification products to a test strip containing allele-specific oligonucleotide probes immobilized as an array of parallel lines. Bound biotinylated sequences were detected using streptavidin-alkaline phosphatase and color substrates. The assay covered 12 mutations in the MEFV gene: E148Q, P369S, F479L, M680I (G/C), M680I (G/A), I692del, M694V, M694I, K695R, V726A, A744S, R761H.

- Severity score. To assess the severity of the disease, we used the Pars severity score10, which accounts for the age of onset, duration and frequency of the attacks, presence of arthritis and ELE, response to colchicine therapy, and presence of amyloidosis. Patients with a score $>10$ were considered to have a severe form of the disease, 5-10 a moderate disease, and $<5$ a mild disease ${ }^{(11)}$.

\section{Statistical Analysis}

Continuous variables were expressed as the mean \pm SD and median (range), and the categorical variables were expressed as a number (percentage). Continuous variables were checked for normality by using Shapiro-Wilk test and were compared by Kruskal Wallis $\mathrm{H}$ test. Percent of categorical variables were compared using Pearson's Chi-square test. All tests were two sided. A p-value $<0.05$ was considered significant. All statistics were performed using SPSS 22.0 for windows (SPSS Inc., Chicago, IL, USA), MedCalc windows (MedCalc Software bvba 13, Ostend, Belgium) and Microsoft Office Excel 2010 for windows (Microsoft Cor., Redmond, WA, USA).

\section{RESULTS}

-This study was done on 55 patients 27 male $(49.1 \%)$ and 28 female $(50.9 \%)$ with mean age \pm SD is 8.28 years \pm 4.27 . Family history was positive in 34 cases $(63.6 \%)$ and negative in 34 cases $(36.4 \%)$. The mean age of diagnosis was $5.47 \pm 2.66$ years and the diagnosis lag was $5.36 \pm 2.55 \mathrm{y}$. The results of the study are shown in tables 1-6.

Table (1): Clinical diagnostic criteria of the studied FMF patients

\begin{tabular}{|l|c|c|}
\hline $\begin{array}{l}\text { Clinical } \\
\text { pictures }\end{array}$ & $\begin{array}{c}\text { Number } \\
\text { (total 55) }\end{array}$ & Percentage (\%) \\
\hline Fever & 53 & $96.4 \%$ \\
\hline $\begin{array}{l}\text { Abdominal } \\
\text { pain }\end{array}$ & 50 & $90.9 \%$ \\
\hline Chest pain & 45 & $81.8 \%$ \\
\hline Arthritis & 30 & $54.5 \%$ \\
\hline Family history & 34 & $61.8 \%$ \\
\hline
\end{tabular}

Table (2): Severity of attacks of the studied FMF patients

\begin{tabular}{|c|c|c|}
\hline & No. & $\%$ \\
\hline \multicolumn{3}{|l|}{ (A) Age of onset } \\
\hline Less than 5 years & 49 & $89.1 \%$ \\
\hline From 6 to 16 & 6 & $10.9 \%$ \\
\hline More than 16 & 0 & $0 \%$ \\
\hline \multicolumn{3}{|c|}{$\begin{array}{l}\text { (B)Duration of attacks } \\
\text { (days) }\end{array}$} \\
\hline Mean \pm SD & $\begin{array}{c}2.96 \pm \\
0.94\end{array}$ & \\
\hline Median (Range) & $3(1-5)$ & \\
\hline \multicolumn{3}{|c|}{ (C)Frequency of attacks } \\
\hline More than $2 /$ month & 24 & $43.6 \%$ \\
\hline $1-2 /$ month & 28 & $50.9 \%$ \\
\hline Less than $1 /$ month & 3 & $5.5 \%$ \\
\hline \multicolumn{3}{|l|}{ (D)Amyloidosis : } \\
\hline Yes & 15 & $27.3 \%$ \\
\hline No & 40 & $72.7 \%$ \\
\hline \multicolumn{3}{|l|}{$\begin{array}{l}\text { (E) Response to } \\
\text { colchicine }\end{array}$} \\
\hline Yes & 51 & $92.7 \%$ \\
\hline No & 4 & $7.3 \%$ \\
\hline \multicolumn{3}{|l|}{ Severity of attack } \\
\hline Mild & 29 & $52.7 \%$ \\
\hline Moderate & 6 & $10.9 \%$ \\
\hline Severe & 20 & $36.4 \%$ \\
\hline
\end{tabular}


Table (3): Genetic analysis of the studied FMF patients

\begin{tabular}{|c|c|c|c|c|c|c|c|}
\hline \multirow{2}{*}{ Gene } & \multirow{2}{*}{ Total } & \multicolumn{2}{|c|}{ Wild gene } & \multicolumn{2}{|c|}{ Heterozygote mutation } & \multicolumn{2}{|c|}{ Homozygote mutation } \\
\hline & & No. & $\%$ & \begin{tabular}{|l|} 
No. \\
\end{tabular} & $\%$ & No. & $\%$ \\
\hline M694V & 55 & 31 & $56.4 \%$ & 15 & $27.3 \%$ & 9 & $16.4 \%$ \\
\hline M694I & 55 & 38 & $69.1 \%$ & 14 & $25.5 \%$ & 3 & $5.5 \%$ \\
\hline V726A & 55 & 42 & $76.4 \%$ & 7 & $12.7 \%$ & 6 & $10.9 \%$ \\
\hline M680I & 55 & 49 & $89.1 \%$ & 3 & $5.5 \%$ & 3 & $5.5 \%$ \\
\hline $\mathrm{R} 761 \mathrm{H}$ & 55 & 46 & $83.6 \%$ & 9 & $16.4 \%$ & 0 & $0 \%$ \\
\hline K695R & 55 & 46 & $83.6 \%$ & 9 & $16.4 \%$ & 0 & $0 \%$ \\
\hline A744S & 55 & 54 & $98.2 \%$ & 1 & $1.8 \%$ & 0 & $0 \%$ \\
\hline I692del & 55 & 54 & $98.2 \%$ & 1 & $1.8 \%$ & 0 & $0 \%$ \\
\hline E148Q & 55 & 54 & $98.2 \%$ & 1 & $1.8 \%$ & 0 & $0 \%$ \\
\hline P369S & 55 & 55 & $100 \%$ & 0 & $0 \%$ & 0 & $0 \%$ \\
\hline F479L & 55 & 55 & $100 \%$ & 0 & $0 \%$ & 0 & $0 \%$ \\
\hline
\end{tabular}

Table (4): Relation between type of genetic mutation and demographic data of patients

\begin{tabular}{|c|c|c|c|c|c|c|c|}
\hline \multirow{3}{*}{ Parameters } & \multirow{2}{*}{\multicolumn{2}{|c|}{$\begin{array}{c}\text { Heterozygote (one gene) } \\
\qquad(\mathrm{N}=15) \\
\end{array}$}} & \multirow{2}{*}{\multicolumn{2}{|c|}{$\begin{array}{c}\text { Compound Heterozygote } \\
(\mathbf{N}=\mathbf{2 2}) \\
\end{array}$}} & \multirow{2}{*}{\multicolumn{2}{|c|}{$\begin{array}{c}\text { Homozygote } \\
(\mathrm{N}=\mathbf{1 8}) \\
\end{array}$}} & \multirow{3}{*}{ p-value } \\
\hline & & & & & & & \\
\hline & No. & $\%$ & No. & $\%$ & No. & $\%$ & \\
\hline \multicolumn{8}{|l|}{ Sex } \\
\hline Male & 8 & $53.3 \%$ & 7 & $31.8 \%$ & 12 & $66.7 \%$ & \multirow[t]{2}{*}{0.08} \\
\hline Female & 7 & $46.7 \%$ & 15 & $68.2 \%$ & 6 & $33.3 \%$ & \\
\hline \multicolumn{8}{|l|}{ Age (years) } \\
\hline Mean \pm SD & \multicolumn{2}{|c|}{$9.77 \pm 6.07$} & \multirow{2}{*}{\multicolumn{2}{|c|}{$\frac{7.36 \pm 3.12}{(2-14)}$}} & \multicolumn{2}{|c|}{$7.17 \pm 3.53$} & \multirow[t]{2}{*}{0.15} \\
\hline Median (Range) & \multicolumn{2}{|c|}{$(2-16)$} & & & \multicolumn{2}{|c|}{$(2-12)$} & \\
\hline \multicolumn{6}{|l|}{ Family history } & & \\
\hline Negative & 8 & $53.3 \%$ & 7 & $31.8 \%$ & 6 & $33.3 \%$ & \multirow[t]{2}{*}{0.36} \\
\hline Positive & 7 & $46.7 \%$ & 15 & $68.2 \%$ & 12 & $66.7 \%$ & \\
\hline \multicolumn{8}{|c|}{ Age at Diagnosis (year) } \\
\hline Mean \pm SD & \multicolumn{2}{|c|}{$6.77 \pm 3.49$} & \multirow{2}{*}{\multicolumn{2}{|c|}{$\frac{4.30 \pm 1.09}{(2-6)}$}} & & 2.04 & \multirow[t]{2}{*}{0.001} \\
\hline Median (Range) & \multicolumn{2}{|c|}{$(2-12)$} & & & \multicolumn{2}{|c|}{$(2-9)$} & \\
\hline \multicolumn{8}{|l|}{$\begin{array}{l}\text { Diagnosis lag } \\
\text { (years) }\end{array}$} \\
\hline Mean \pm SD & \multicolumn{2}{|c|}{$6.77 \pm 3.49$} & \multirow{2}{*}{\multicolumn{2}{|c|}{$\frac{4.30 \pm 1.09}{(2-6)}$}} & \multirow{2}{*}{\multicolumn{2}{|c|}{$\frac{5.50 \pm 2.43}{(2-9)}$}} & \multirow[t]{2}{*}{0.01} \\
\hline Median (Range) & \multicolumn{2}{|c|}{$(2-12)$} & & & & & \\
\hline
\end{tabular}

Table (5): Relation between type of genetic mutation and clinical diagnostic criteria

\begin{tabular}{|c|c|c|c|c|c|c|c|}
\hline \multirow{3}{*}{ Parameters } & \multirow{2}{*}{\multicolumn{2}{|c|}{$\begin{array}{c}\text { Heterozygote (one gene) } \\
(\mathrm{N}=15)\end{array}$}} & \multirow{2}{*}{\multicolumn{2}{|c|}{\begin{tabular}{|c|} 
Compound Heterozygote \\
$(\mathbf{N}=\mathbf{2 2})$
\end{tabular}}} & \multirow{2}{*}{\multicolumn{2}{|c|}{$\begin{array}{c}\text { Homozygote } \\
(\mathrm{N}=18)\end{array}$}} & \multirow{3}{*}{ p-value } \\
\hline & & & & & & & \\
\hline & No. & $\%$ & No. & $\%$ & No. & $\%$ & \\
\hline \multicolumn{8}{|l|}{ Fever } \\
\hline Present & 14 & $93.3 \%$ & 21 & $95.4 \%$ & 18 & $100 \%$ & \multirow[t]{2}{*}{0.57} \\
\hline Absent & 1 & $6.7 \%$ & 1 & $4.6 \%$ & 0 & $0.00 \%$ & \\
\hline \multicolumn{8}{|l|}{ Abdominal pain } \\
\hline Present & 12 & $80 \%$ & 20 & $90.9 \%$ & 18 & $100 \%$ & \multirow[t]{2}{*}{0.13} \\
\hline Absent & 3 & $20 \%$ & 2 & $9.1 \%$ & 0 & $0.00 \%$ & \\
\hline \multicolumn{8}{|l|}{ Chest pain } \\
\hline Present & 6 & $40 \%$ & 7 & $31.9 \%$ & 12 & $66.7 \%$ & \multirow[t]{2}{*}{0.078} \\
\hline Absent & 9 & $60 \%$ & 15 & $68.1 \%$ & 6 & $33.3 \%$ & \\
\hline \multicolumn{8}{|l|}{ Arthritis } \\
\hline Present & 2 & $13.3 \%$ & 4 & $18.2 \%$ & 9 & $50 \%$ & \multirow[t]{2}{*}{0.029} \\
\hline Absent & 13 & $87.7 \%$ & 18 & $81.8 \%$ & 9 & $50 \%$ & \\
\hline \multicolumn{8}{|l|}{ Family history } \\
\hline Present & 7 & $46.7 \%$ & 13 & $59.1 \%$ & 14 & $77.8 \%$ & \multirow[t]{2}{*}{0.176} \\
\hline Absent & 8 & $53.3 \%$ & 9 & $40.9 \%$ & 4 & $22.2 \%$ & \\
\hline
\end{tabular}


Table (6): correlation between type of genetic mutation and clinical severity

\begin{tabular}{|c|c|c|c|c|c|c|c|}
\hline Parameters & \multirow{2}{*}{\multicolumn{2}{|c|}{$\begin{array}{c}\begin{array}{c}\text { Heterozygote } \\
\text { (one gene) }\end{array} \\
(\mathrm{N}=15)\end{array}$}} & \multirow{2}{*}{\multicolumn{2}{|c|}{$\begin{array}{c}\begin{array}{c}\text { Compound } \\
\text { Heterozygote }\end{array} \\
(\mathbf{N}=\mathbf{2 2})\end{array}$}} & \multicolumn{2}{|c|}{ Homozygote } & \multirow[t]{3}{*}{ p-value } \\
\hline & & & & & & & \\
\hline & No. & $\%$ & No. & $\%$ & No. & $\%$ & \\
\hline \multicolumn{8}{|l|}{ Age of onset } \\
\hline Less than 5 years & 11 & $73.3 \%$ & 20 & $90.9 \%$ & 18 & $100 \%$ & \multirow[t]{2}{*}{0.072} \\
\hline From 6 to $16 \mathrm{y}$ & 4 & $26.7 \%$ & 2 & $9.1 \%$ & 0 & $0.0 \%$ & \\
\hline \multicolumn{7}{|l|}{ Frequency of attacks } & \multirow{4}{*}{0.004} \\
\hline More than $2 /$ month & 2 & $13.3 \%$ & 10 & $45.4 \%$ & 12 & $66.7 \%$ & \\
\hline One to two / month & 10 & $66.7 \%$ & 12 & $55.6 \%$ & 6 & $33.3 \%$ & \\
\hline Less than one / month & 3 & $20.0 \%$ & 0 & $0.0 \%$ & 0 & $0.0 \%$ & \\
\hline \multicolumn{8}{|l|}{ Amyloidosis : } \\
\hline Yes & 1 & $6.66 \%$ & 6 & $27.3 \%$ & 8 & $44.4 \%$ & \multirow[t]{2}{*}{0.052} \\
\hline No & 14 & $93.4 \%$ & 16 & $72.7 \%$ & 10 & $55.6 \%$ & \\
\hline \multicolumn{7}{|l|}{ Response to colchicine } & \multirow{3}{*}{0.35} \\
\hline Yes & 15 & $100 \%$ & & & & & \\
\hline No & 0 & $0.0 \%$ & $\begin{array}{c}22 \\
0\end{array}$ & $\begin{array}{l}100 \% \\
0.0 \%\end{array}$ & $\begin{array}{c}17 \\
1\end{array}$ & $\begin{array}{c}94.4 \% \\
5.6 \%\end{array}$ & \\
\hline \multicolumn{8}{|l|}{ Severity of attack } \\
\hline Mild (less than 5) & 13 & $86.7 \%$ & 8 & $36.4 \%$ & 4 & $22.2 \%$ & \multirow[t]{3}{*}{0.004} \\
\hline Moderate $(5-10)$ & 2 & $13.4 \%$ & 8 & $36.4 \%$ & 8 & $44.4 \%$ & \\
\hline Severe (more than 10) & 0 & $0.0 \%$ & 6 & $27.2 \%$ & 6 & $33.4 \%$ & \\
\hline
\end{tabular}

\section{DISCUSSION}

This study was done on 55 patients 27 male $(49.1 \%)$ and 28 female (50.9\%) with mean age \pm SD is 8.28 years \pm 4.27 . This finding is nearly similar to previously published data from Egypt ${ }^{(13)}$ and from Germany ${ }^{(14)}$ but in other publications males were more predominant than females ${ }^{(15)}$.

The mean age of diagnosis was $5.47 \mathrm{y} \pm 2.66$ years and the diagnosis lag was $5.36 \pm 2.55 \mathrm{y}$. These data are consistent with that published from Egypt ${ }^{(13)}$ and from Germany ${ }^{(14)}$ but younger age was found in Iran and Turkey $(\mathbf{1 6}, \mathbf{1 7 )}$.

Fever was the most prevalent manifestation in our patients as $96.3 \%$ of them experienced fever and the second most frequent symptom was abdominal pain $90.9 \%$ followed by chest pain $81.8 \%$ of patients. This matches with data from El Gezery et al. ${ }^{(15)}$ Bidari $\boldsymbol{e t}$ $\boldsymbol{a l} .{ }^{\left({ }^{16)}\right.}$, and from Tunca et $\boldsymbol{a l} .{ }^{(17)}$ and mismatchs with Lainka et al. ${ }^{(14)}$ and Yilmaz et al. ${ }^{(18)}$, where the main manifestation was abdominal pain. This difference may be due to the fact that we worked on patients from the same ethnic origin but Lainka et al. ${ }^{(14)}$ worked on patients from different ethnic origin.

Family history was positive in $61.8 \%$ and this is higher than data published by El Gezery et al. (15) (25.3\%) who worked on both adult and children and more than that published by Yilmaz et al. ${ }^{(\mathbf{1 8 )}}$.

Most of our patients became symptomatic before the age of 5 years $49(89.1 \%)$ and only 6 patients after 5 years of age (10.9\%). This is similar to Lainka $\boldsymbol{e t}$ $\boldsymbol{a l} .^{(14)}$ but younger than that was found by Yilmaz et al.
(18) but in most of published data the age of onset was before 10 years.

The mean time and SD of the duration of attacks for our patients were $2.96 \pm 0.94$ with a range from 1 to 5 days and a median of 3 days. These data are similar to that published by Lainka et al. ${ }^{(14)}$.

Most of our patients experienced attacks between one month to 3 months (50.9\%) then 43.6 less than one month and only $5.5 \%$ had attacks in a frequency more than 3 months.

Fifteen patients had amyloidosis at diagnosis (27.3\%) while forty patients did not have elevated amyloid at diagnosis $(72.7 \%)$. This is near to that published by Schwabe and Peters ${ }^{(19)}$ but higher frequency was found by Lainka et al. ${ }^{(14)}$, Tunca $e t$ $\boldsymbol{a l} .^{\left({ }^{(17)}\right.}$. This high level of amyloidosis at diagnosis was related partly to the long diagnosis lag (time from appearance of symptoms till final diagnosis of FMF and partly due to no adherence to treatment) and various publications have reported the risk of amyloidosis in FMF patients who are homozygous for the M694V mutation in the MEFV gene ${ }^{\mathbf{2 0}, \mathbf{2 1})}$.

Fifty one patient showed good response to colchicine $(92.7 \%)$ while only four did not show response (7.3\%). This is similar to data published by Tunca et $\boldsymbol{a l} .{ }^{(17)}$ and the response was variable in patients from complete to partial and this variability was related mainly to the adherence to treatment and the dose. 
The severity of attacks were mild in 29 patients $(52.7 \%)$ and moderate in 6 patients $(10.9 \%)$ and sever in 20 patients $(36.4 \%)$.

M694V was the most prevalent mutation followed by M694I, V726A, M680I, R761H and K695R respectively. A744S, I692del and E148Q mutations were found only in one patient and all were heterozygous and lastly P369S and F479L mutations were not found in any of our patients. our data was similar to data published by Tunca et al. ${ }^{(17)}$ in Turkish population and Linkah et al. ${ }^{(14)}$ in Germany as they found that M694V mutation was the most common but followed by M680I and V726A and to a lesser extent, other mutations such as E148Q, M694I, R761H, K695R, E148V and P369S were identified. Our data were also similar to data published Ben-Chetrit and Touitou (22) who stated that the E148Q, M680I, M694V, M694I and V726A mutations are responsible for more than $80 \%$ of FMF cases in the Middle Eastern region. But our data is not similar to that published by El Gezery et al. ${ }^{(15)}$ who found that the most common were M694I (34\%), E148Q (22.7\%), V726A (15.6\%), M680I (12.1\%), and M694V (7.8\%) and our data is not similar to that published by Sari et al. ${ }^{(23)}$ who stated that the most common mutation in Arabs was V726A, M680I, M694V, M694I and E148Q. Instead of variability in prevalence of different mutations but the most common five mutations were the same, so difference in prevalence may be related partially to different techniques in DNA extraction or analysis and to the fact that El Gezery et al. found mutations in only $57 \%$ of his study group but in our study only patients with mutations were involved ${ }^{(15)}$.

In our study, compound heterozygous mutations were the commonest (44\%) followed by homozygous mutation (33\%) and lastly heterozygous mutations (23\%), this is similar to data published by El Gezery $\boldsymbol{e} t$ al. ${ }^{(15)}$ who found two mutant alleles were detected in $100(31.6 \%)$ patients, of whom 20 were homozygous and 80 were compound heterozygous. A single mutant allele was detected in $82(25.9 \%)$ patients, and no mutations could be detected in 134 (42.4\%) patients.

Researchers have claimed that there is a relationship between FMF symptoms and the genotype. There was no correlation between type of mutation and age, sex or family history of FMF in our patients but the homozygous and compound heterozygous patients were significantly diagnosed in younger age than heterozygous patients and the time lag between appearance of symptoms and diagnosis was significantly shorter than heterozygous patients. These findings are consistent with that published by Yilmaz et al. ${ }^{(18)}$ regarding age of onset and diagnosis lag although they did not found any significant correlation regarding the age of diagnosis.

Regarding the diagnostic criteria there was no significant correlation between type of mutation and presence of fever, abdominal pain or family history although the family history was prominent in patients with homozygous mutations but there was significant correlation with chest pain and arthritis. These data are partially consistent with that of Yilmaz et al. ${ }^{(\mathbf{1 8 )}}$ who found significant correlation with fever, chest pain and arthritis but did not found any significant correlation with abdominal pain or rash.

There was significant correlation between the type of mutation and severity of attacks according to Pars score being more severe in patients with homozygous and compound heterozygous mutations. These data are consistent with that of Yilmaz et al. ${ }^{(\mathbf{1 8})}$ and Guz et al. ${ }^{\text {(24) }}$ who stated that in FMF patients of Arab descent, the highest disease severity was associated with homozygos M694V and compound heterozygous M694V/V724A.

There was significant correlation between the type of mutation and frequency of attacks being more in patients with homozygous and compound heterozygous mutations. These data are consistent with that of Yilmaz et al. ${ }^{(18)}$ who found more frequent attacks in homozygous and heterozygous before treatment but there was no difference after treatment.

There was no significant correlation between the type of mutation and duration of attacks, presence of amyloidosis at diagnosis or response to treatment with colchicine. These data are consistent with that of Tunca et al. ${ }^{(17)}$ and Yilmaz et al. $^{\left({ }^{(18)}\right.}$ who noted that amyloidosis is less common in Arab patients with FMF and that the disease seems to run a milder course than in other ethnic groups. In a mixed cohort of 220 Arab and Jewish patients with FMF, Gershoni-Baruch et al. (25) noted that homozygosity for M694V and the V726A=E148Q genotype were associated with a severe course and the highest risk for amyloidosis.

\section{CONCLUSION}

In Egypt there is no significant difference between homozygous and heterozygous FMF patients regarding their clinical presentations but type of mutation affects the severity of clinical presentation.

\section{REFERENCES}

1. Brik R, Kepten I, Berant M et al. (1999): Familial Mediterranean fever: clinical and genetic characterization in a mixed pediatric population of Jewish and Arab patients. Pediatrics, 103:70-6.

2. Berkun Y, Eisenstein E (2014): Diagnostic criteria of familial Mediterranean fever. Autoimmun Rev., 13(45):388-90.

3. Pras M (1998): Familial Mediterranean Fever: from the clinical syndrome to the cloning of the pyrin gene. Scand J Rheumatol., 27:92-97.

4. Livneh A and Langevitz $P$ (2000): Diagnostic and treatment concerns in familial Mediterranean fever. Baillieres Best Pract Res Clin Rheumatol., 14:477-498.

5. Livneh A, Langevitz $P$, Zemer $D$ et al.( 1997): Criteria for the diagnosis of familial Mediterranean fever. Arthritis Rheum., 40:1879-85. 
6. Yalçinkaya F, Ozen S, Ozçakar Z et al. (2009) A new set of criteria for the diagnosis of familial Mediterranean fever in childhood. Rheumatology (Oxford), 48(4):3958.

7. Ozçakar Z, Yalçınkaya F, Cakar Net al. (2011): Application of the new pediatric criteria and Tel Hashomer criteria in heterozygous patients with clinical features of FMF. Eur J Pediatr., 170(8):1055-7.

8. Touitou I (2001): The spectrum of familial Mediterranean fever (FMF) mutations. Eur J Hum Genet., 9:473-483.

9. Giancane $\mathrm{G}$, Ter Haar $\mathrm{N}$, Wulffraat $\mathrm{N}$ et al. (2015): Evidence-based recommendations for genetic diagnosis of familial Mediterranean fever. Ann Rheum Dis., 74(4):635-41.

10. Pras E, Aksentijevich I, Gruberg L et al. (1992): Mapping of a gene causing familial Mediterranean fever to the short arm of chromosome 16. N Engl J Med., 326:1509-1513.

11. Pras E, Livneh A, Balow J et al. (1998): Clinical differences between North African and Iraqi Jews with familial Mediterranean fever. Am J Med Genet., 75:216-9.

12. Pras E, Aksentijevich I, Levy E et al. (1994): The gene causing familial Mediterranean fever maps to the short arm of chromosome 16 in Druze and Moslem Arab families. Hum Genet., 94:576-577.

13. Zarouk W, El-Bassyouni H, Shehata G et al. (2012): Clinical and molecular diagnosis of MEFV gene mutations in egyptian patients with familial Mediterranean fever. Journal of Applied Sciences Research, 9(4): 3037-3044.

14. Lainka E, Bielak M, Lohse $P$ et al. (2012) Familial Mediterranean fever in Germany: epidemiological, clinical, and genetic characteristics of a pediatric population. Eur J Pediatr., 171:1775-1785.

15. El Gezery D, Abou-Zeid A, Hashad D et al. (2010): MEFV gene mutations in Egyptian patients with familial Mediterranean fever. Genet Test Mol Biomarkers, 14: 263-268.

16. Bidari A, Ghavidel-Parsa B, Najmabadi $\mathrm{H}$ et al. (2010): Common MEFV mutation analysis in 36 Iranian patients with familial Mediterranean fever: clinical and demographic significance. Mod Rheumatol., 20:566-572.

17. Tunca M, Akar S, Onen F (2005): Familial Mediterrean fever (FMF) in Turkey: results of a nationwide multicenter study. Medicine (Baltimore), 84:1-11.

18. Yilmaz R, Ozer S, Ozyurt H et al. (2009): Familial Mediterranean fever gene mutations in the inner northern region of Turkey and genotype-phenotype correlation in children. J Paediatr Child Health, 45:641645.

19. Schwabe $A$ and Peters $R$ (1974): Familial Mediterranean fever in Armenians. Analysis of 100 cases. Medicine (Baltimore), 53: 453-62.

20. Kasifoglu T, Bilge S, Sari I et al. (2014): Amyloidosis and its related factors in Turkish patients with familial Mediterranean fever: a multicentre study. Rheumatology (Oxford), 53(4):741-5.

21. Akpolat T, Ozkaya O, Ozen S (2012): Homozygous M694V as a risk factor for amyloidosis in Turkish FMF patients. Gene, 492: 285-9.

22. Ben-Chetrit $E$ and Touitou I (2009): Familial Mediterranean fever in the world. Arthritis Rheum., 61: 1447-53.

23. Sari I, Birlik M, Kasifoglu $T$ (2014): Familial Mediterranean fever: an updated review. Europen Journal of Rheumatology, 1(1):21-33.

24. Guz G, Kanbay M, Ozturk M (2009): Current perspectives on familial Mediterranean fever. Curr Opin Infect Dis., 22:309-315.

25. Gershoni-Baruch $\mathrm{R}$, Shinawi $\mathrm{M}$, Leah $\mathrm{K}$ et al. (2001): Familial Mediterranean fever: prevalence, penetrance and genetic drift. Eur J Hum Genet, 9:634637. 